\title{
Experiential Learning in the Classroom: An Accounting Cycle Simulation Project
}

\author{
Richard Sathe \\ University of St. Thomas - Minnesota \\ Wen Yu \\ University of St. Thomas - Minnesota
}

Kolb and Fry (1975) discussed the dynamics of learning and suggested the four-stage experiential learning model as "a holistic approach to the learning process." We designed a "simulation experiential learning approach." We integrated a virtual business simulation into an accounting cycle project to incorporate the experiential learning model into a classroom activity. Specifically, students (1) created their business activities in the simulation to develop concrete business experience, (2) observed business operations and applied accounting cycle procedures to record and report these activities, (3) analyzed and evaluated business operations as captured in their accounting records and reports, and (4) used these reports to make informed decisions in their subsequent business activities. Most students considered the project effective and relevant. They found it interesting and were motivated to put forth time and effort to the project. They reported that the project required a broad range of skills. Upon completion of the project, students showed improvement along Anderson and Krathwohl's (2001) factual, conceptual, procedural, and metacognition knowledge dimensions in learning the subject matter.

Keywords: experiential learning, simulation experiential learning approach, accounting cycle project

\section{INTRODUCTION}

The accounting cycle is a key topic in introductory financial accounting courses. It also serves as a foundational topic for intermediate accounting. Although most textbooks offer a list of business transactions for an accounting cycle project, their focus is procedural. We integrated a virtual business simulation and designed the project to enable students to experience the accounting cycle within the framework of the fourstage experiential learning model (Kolb and Fry, 1975; Kolb, 1984; Kolb and Kolb, 2005, among others). Specifically, our project enabled students to (1) create and simulate their own business activities, (2) apply the accounting cycle to record and report these activities, (3) analyze their financial records and reports, and (4) make informed decisions in subsequent business acitivities on the basis of these reports.

The experiential learning model, proposed by Lewin et al. (1939) and elaborated by Kolb and Fry (1975), views learning as an integrated and dynamic process of a four-stage cycle: (1) immediate concrete experience, followed by (2) observations of this experience with data collection, which is then used in (3) data analysis and abstract summary, which provide feedback for (4) modification of choices in new experiences. It suggests that effective learning occurs when a learner executes all four stages of the model. 
In light of Kolb and Fry (1975), Kolb (1984), and Kolb and Kolb (2005), we define experiential learning as a learning process that facilitates the implementation of the abovementioned four-stage cycle in creating knowledge and learning subject matter through experience. ${ }^{1}$ We integrated a virtual business simulation into an accounting cycle project to create a quasi-"real world" context for a classroom activity. This blending of a simulation with an accounting cycle goes beyond the usual procedural focus of most accounting cycle projects. It puts students in the position of decision makers who not only prepare accounting records and reports, but also make and modify business decisions based on accounting cycle information. Students therefore (1) create and experience, (2) observe and record, and (3) analyze and interpret their simulated business activities, and finally (4) modify and test new business decisions and transactions in a cyclical manner for a "holistic" understanding of the subject matter. To our knowledge, we are the first to integrate a business simulation into an accounting cycle project with the intent of incorporating the four-stage experiential learning model. We refer to our design as the "simulation experiential learning approach" to an accounting cycle project.

We follow Anderson and Krathwohl (2001) to validate the efficacy of our design. Anderson and Krathwohl expanded Bloom's (1956) taxonomy of learning domains. They revised Bloom's cognitive processes (i.e., remembering, understanding, applying, analyzing, evaluating, and creating) and elaborated four knowledge dimensions, including factual, conceptual, procedural, and metacognition. Using the simulation experiential learning approach, our students simulate, observe, record and report their business activities. As they remember, understand, and apply the accounting cycle, we seek to help students comprehend the factual, conceptual and procedual knowledge dimensions. The design of the simulation experiential learning approach also encourages students to analyze, evaluate and interpret the information developed in the accounting cycle in order to modify subsequent business decisions and create future activities. This supports student learning along the high-level cognitive dimension of metacognition.

Upon completion of the accounting cycle project, most students felt the simulation experiential learning approach effective and interesting. Their performance in pre- vs. post- project knowledge tests demonstrated significant progress along all four knowledge dimensions (i.e., factual, conceptual, procedural, and metacognition) of the subject matter. These students, as compared to those in the traditional project approach without a business simulation, suggested that they were more motivated to put forth time and effort to the project. They felt that the simulation project required a broad range of skills (i.e., both basic technical understanding of the topic and other more advanced analytical skills). They performed better in the post-project knowledge tests in answering questions in the metacognition dimension.

\section{LITERATURE REVIEW}

Dewey $(1897,1938)$ discussed the importance of experience in education and illustrated that, “...education must be conceived as a continuing reconstruction of experience..." (Dewey, 1897, p.79). Lewin et al. (1939) proposed the experiential learning model in their work on leadership and group dynamics. Kolb and Fry (1975) elaborated the model and discussed applications of the model as "a holistic approach to the learning process" (Kolb and Fry, 1975, p.56). The model describes the dynamics of the learning process as a four-stage cycle. Learners engage with their subject matter in the four-stage cycle to (1) experience, (2) observe and reflect, (3) analyze and theorize, and (4) modify and test in new experiences, all in a cyclical manner.

Kolb (1984) and Kolb and Kolb (2005) further extended the model and discussed its educational applications. They suggested that learners experience, reflect, conceptualize, and test in the four-stage cycle to enable deep learning. McCarthy (2010) illustrated the four-stage experiential learning process as, "Do, Reflect, Think, and Apply" learning activities in accounting education. To engage students in experiential learning, Lafond and Wentzel (2015) used student interviews with small businesses as a learning activity for cost accumulation. They showed that students responded positively to a realistic experiential assignment and students met or exceeded instructor expectations in achieving learning objectives. ChmielewskiRaimondo et al. (2016) positioned and assessed their field-trip experiences within the framework of the experiential learning model. They documented evidence of enhanced student learning with respect to the 
four-stage cycle. Huber et al. (2017) developed three active learning assignments in their introductory financial accounting course and demonstrated effective learning in the students' real-world skill sets.

Blankley et al. (2017) surveyed accounting educators regarding the use of different teaching and learning techniques to engage students in accounting education. They recommended to incorporate more active learning in the accounting curriculum. More recently, Butler et al. (2019) advocated for the use of experiential learning. They suggested that experiential delivery enhances student development in "critical thinking skills, problem-solving expertise, and the ability to handle complex issues in accounting practice" (Butler et al., 2019, p.14). Gittings et al. (2020) reviewed the accounting literature on the use of experiential learning activities. They found that experiential learning enhances student attitude and satisfaction of learning, enables authentic application of concept and theory, and improves student comprehension of technical knowledge.

\section{PROJECT OVERVIEW AND LEARNING OBJECTIVES}

The accounting cycle has long been a foundational topic in financial accounting. Most pedagogical research (for example, Jones and Roberts, 2005; Brink, 2013; Sargent, 2013; Fanning and Grant, 2017; Jones et al., 2019, among others) has a procedural emphasis and mainly focuses on the development of cases and projects in which students progress through the steps in an accounting cycle with basic or complex business transactions given. Bergner and Brooks (2017) used the game Monopoly as a learning tool to review for an accounting cycle exam. They showed that students playing Monopoly outperformed the ones without review; however, their exam performance was statistically the same as the ones with traditional review. A recent study by Porter (2019) developed an integrated multi-step accounting cycle project. It extended the traditional procedural aspect of an accounting cycle and incorporated other elements, for example, consideration of tax implications, financial statement updates and financial statement analysis.

We integrated a virtual business simulation into an accounting cycle project to create a business context within the four-stage experiential learning model. Green and Calderon (2005) designed both "direct and indirect course-embedded assessment techniques" to validate the effectiveness of the simulation-based pedagogy in student learning. They demonstrated that in using audit risk simulations, students not only perceived a positive learning experience but also improved their performance with enhanced risk assessment skills in auditing. More recently, Phillips and Graeff (2014) developed a simulation for merchandise related transactions to build student confidence and sustain student deeper understanding in accounting. Zeigler (2015) implemented a business simulation in introductory managerial accounting. He showed increased student engagement in integration learning. His students also outperformed peer groups in assessment exams in answering accounting related questions.

We implemented the simulation in a classroom activity, in order to enrich students understanding as they perform all four stages of experiential learning in this quasi-"real world" accounting cycle project. This design not only requires students to complete the procedures in the accounting cycle, but also enables students to create organic business transactions, to record and report the results of their transactions in the accounting cycle, to analyze and compare their business performance, and based on their analysis to make and modify future business decisions. The iteration of creating, recording, reporting, analyzing, and modifying their own transactions in a virtual simulation enables the cyclical four-stage process in experiential learning. It also provides an interactive learning experience of strategic business decisionmaking within an accounting cycle.

We used Anderson and Krathwohl's (2001) taxonomy of learning, teaching and assessing to examine the project's efficacy in the factual, conceptual, procedural, and metacognition knowledge dimensions. There are two primary goals for students in this project; first, to remember, understand and apply the procedures in the accounting cycle, and second, to analyze and evaluate accounting information to make subsequent business decisions. We assessed student learning with both student self-assessment questionnaires and student performance results, as described in the Case Efficacy section. The specific learning objectives are that students would be able to: 
1. Describe and explain the business context of the accounting cycle in a hands-on business simulation. [factual and conceptual dimensions]

2. Apply and complete accounting cycle procedures for business activities in the simulation and with additional information provided by the instructor. [factual, conceptual, and procedural dimensions]

3. Analyze financial statements that they prepared in the accounting cycle, and on that basis, evaluate business performance and make recommendations for future business activities. [metacognition dimension]

\section{THE PROJECT}

In this project, students gain hands-on experience in accounting cycle procedures in a virtual business simulation. This simulation experiential learning approach enables students to create their own business activities. Within the structure of the accounting cycle, it allows students to prepare accounting records and financial reports to capture the impact of these activities on business performance outcomes. The project also helps students further analyze and evaluate these records and reports in order to make subsequent business decisions and create future business transactions.

\section{Phase 1}

In Phase1, we use and modify GoVenture Accounting Game ${ }^{2,3}$ to provide students a virtual business environment (see Appendix 1.1). This simulation puts students in the role of business owners, who make a series of decisions to operate their businesses which consist of mobile carts.

Students choose a type of merchandise (for example, hot dogs, ice cream, electronics, and others) and financing for their business (for example, through borrowing, self-contributing, or a combination of both). To start their business operations, students also need to obtain their equipment (i.e., the mobile cart), licenses and permits, and insurance. On a daily operational basis, students decide their location (for example, by a factory site, shopping mall, amusement park, and other locations) and hours of operation (for example, during regular work hours, at lunch time, taking the day off, and other time windows). They also need to decide how much merchandise to purchase and carry on their cart, the selling price of their merchandise, whether to hire additional salespersons, and which advertising channels they will use for the day. Once these decisions are made, GoVenture Accounting Game simulates operations of the business and provides the results of daily sales and cost of goods sold (see Appendix 1.2).

At the end of each day, additional business and financial reports (see an example in Appendix 1.3) are provided in the simulation. ${ }^{4}$ For example, a daily summary includes the number of customers, market share, sales and gross profit, selling expenses, and the cash balance at the end of the day. Other reports and charts include sales by product, market share over time, customer satisfaction, and customer comments. Since the game mostly simulates cash-based activities, it generates primarily cash-based financial statements (see Appendix 1.4). As we discuss in Phase 2, for the accounting cycle procedures in the project, we modify these activities from the simulation and provide additional information to incorporate accrual-based transactions. We discuss the differences between the cash basis and the accrual basis of accounting in a class prior to the simulation. During the simulation, we remind students of the differences when they are asked to review and analyze this information, upon which to make/revise their decisions for the next day's operations.

In Phase 1, we ask students to run their business simulation for a period of 30 days with the goal of maximizing their profit during the period. The instructor can adjust the length of the period to adapt to class time. At the end of the simulation game, students describe the changes they made in their daily business decisions. They share insights regarding why they made such changes and how the changes affected subsequent operations. When the students discuss their business decisions and changes, they (or the instructor) relate these decisions and changes to their analyses and evaluations of business and financial reports. 


\section{Phase 2}

Upon completion of Phase 1, students record their business activities from the simulation for the 30day period. To instruct students on the accrual basis of accounting, we add required business activities with additional information for journal entries and adjustments (see Appendix 2). Alternatively, the instructor can choose to provide more general guidelines and let students summarize and describe their own activities. The instructor can also modify and emphasize different transactions.

We then review with students the description of their business transactions, based on which they complete the accounting cycle procedures, outside of class, using Excel worksheets. The instructor can choose whether to use Excel for the project. Other deliverable formats (for example, a paper copy) can also be used for the purpose of learning the accounting cycle.

In Phase 2, we also ask students to compare the financial statements automatically generated from the simulation (of which we ask students to take a screenshot at the end of the 30-day period from the simulation in Phase 1) to the financial statements that they prepared from the accounting cycle. Students (or the instructor) can then discuss the accrual basis of accounting and explain why the accrual basis and revenue recognition and matching principle are required for external financial reporting. Students also compare their results to each other and evaluate their business performance outcomes using the financial statements they prepared. Additional inferences can be drawn to relate to their earlier business decisions and revisions from the simulation. Last, students are asked to analyze their financial records and reports to assess their business decisions and revisions, and to provide suggestions and plans for future business activities.

The final deliverables of the project include (1) student descriptions of their business transactions from the simulation, (2) Excel worksheets for the accounting cycle, and (3) student discussions of their business decisions, revisions, and suggestions based on their experience in the simulation and their analysis of financial statements and reports they prepared.

\section{IMPLEMENTATION GUIDELINES}

The project can be used in an undergraduate introductory financial accounting course or an undergraduate intermediate accounting course that includes review of the accounting cycle. It can be assigned to individual students or teams. It can be modified to include more decision options in the simulation and to supplement the simulation with other business transactions if the instructor wishes to emphasize the recording, reporting and analysis of different business decisions.

Our project is designed to simulate a typical accounting cycle in a merchandising company. Phase 1 focuses on the simulation activities. It emphasizes the business context in which financial information is generated and used to make business decisions. We suggest that, at the beginning of the simulation, the instructor discuss, and explicitly identify, a performance goal for the simulation (for example, to maximize profit). This encourages students to analyze and use financial information as they make and revise daily decisions toward the performance goal.

It can be helpful if the instructor runs the first day simulation with students to introduce the options in the various business decisions and to demonstrate the use of business and financial reports. The suggested time frame for a 30-day-period in-class simulation is 45-60 minutes. The instructor can adjust the length of the accounting period to accommodate shorter or longer class periods. However, it is essential to let students run the simulation for a number of days, so they can make business decisions, observe and analyze the results of these decisions, revise subsequent activities, and test and re-assess business performance. This repetitive process allows students to progress through the four-stage experiential learning model as they continuously use financial information to make, evaluate, and revise business decisions. Upon completion of the simulation, the instructor can engage with the students to compare their operational performance and discuss how these results relate to business decisions and revisions.

In the transition from Phase 1 to Phase 2, students describe and summarize their business transactions from the simulation. We provide additional information to supplement the simulation with accrual-based activities (see Appendix 2). The instructor can modify this supplemental information, or alternatively, provide more general guidelines. It is helpful if the instructor can review student descriptions and the 
additional information on the transactions. This ensures that students have the proper information to move to the accounting cycle procedures in Phase 2. It also helps students observe how their business decisions flow into the accounting records, which facilitates the discussions to relate business activities to financial information in Phase 2. Since GoVenture Accounting Game automatically generates cash-based financial statements at the end of the 30-day Phase 1 period, we ask students to take a screenshot of these financial statements, so that they can compare and contrast to their own financial statements on the accrual basis from Phase 2. We suggest assigning the project in time to complete Phase 1 and the transition steps at least a week before the final due date of the project.

Phase 2 requires students to complete accounting cycle procedures to record and report their simulation activities with the provided additional information. It also requires students to evaluate and relate business performance to their simulation decisions, based on which to explain and make recommendations for subsequent business decisions. If the instructor wishes, financial statement analysis can also be incorporated into this phase.

We provide students with Excel worksheets for the accounting cycle procedures, including general journal, general ledger, pre-closing trial balance, financial statements, and post-closing trial balance. The instructor can decide whether other deliverable formats (for example, a paper copy) are appropriate. Upon completion of the accounting cycle, we engage students in class discussions about their experience in the simulation and in completing the accounting cycle. The instructor can direct the discussions, so that students review their four-stage experiential learning experience (i.e., creating business decisions, gathering data through the accounting cycle, analyzing financial statements and reports, and revising subsequent business activities). The instructor can also include discussions on the comparison between the cash basis and the accrual basis of accounting.

\section{CASE EFFICACY}

This accounting cycle project in the "simulation experiential learning approach" was successfully used in two sections of intermediate accounting in 2019. In the prior semester, a traditional accounting cycle project was assigned to students in the same course taught by the same instructor. We refer to this as the "traditional project approach." In the traditional project approach, a list of similar business transactions was provided to students. Students also completed accounting cycle procedures in Excel worksheets using the accrual basis of accounting. The traditional approach did not involve a business simulation. It did not let students create and revise their business activities. Therefore, the potential to observe how business decisions impact and flow into accounting records and the potential use of financial reports to evaluate and thus revise business decisions were limited. We gathered data ${ }^{5}$ from both the traditional project and simulation experiential learning approaches. The data from the traditional project approach served as a baseline to further demonstrate the efficacy of the simulation experiential learning approach. We designed and used both student self-assessment questionnaires and student pre- vs. post-project knowledge tests to assess student learning along the factual, conceptual, procedural, and metacognition knowledge dimensions.

Table 1 reports the participants' demographic information. Thirty-two students, who completed the simulation project participated the study. The sample size is comparable to 34 students who used the traditional project approach in the prior semester. A narrow majority of the students in the simulation experiential learning approach (52\%) indicated that they preferred experiential learning (as compared to other learning styles, including visual, auditory, and writing/reading). More students in the simulation experiential learning approach took this intermediate accounting course in their sophomore year (44\% compared to $15 \%$ in the traditional project approach). These students were more likely to complete the project immediately after their introductory financial accounting course but with less experience in other accounting courses. Although their overall GPAs were higher than those of the students in the traditional project approach, their GPAs in the introductory financial accounting course were comparable. Students under both the experiential learning and traditional project approaches were either accounting or finance majors (this intermediate accounting course is required for both majors). There were more male students who participated in the study. 
TABLE 1

STUDENT DEMOGRAPHICS

\begin{tabular}{|c|c|c|c|}
\hline Variable & Full Sample & $\begin{array}{c}\text { Experiential } \\
\text { Approach }\end{array}$ & $\begin{array}{l}\text { Traditional } \\
\text { Approach }\end{array}$ \\
\hline \# Observations & 66 & 32 & 34 \\
\hline \multicolumn{4}{|l|}{ Major } \\
\hline Accounting & $39 \%$ & $41 \%$ & $38 \%$ \\
\hline Finance & $61 \%$ & $59 \%$ & $62 \%$ \\
\hline \multicolumn{4}{|l|}{ Gender } \\
\hline Male & $83 \%$ & $84 \%$ & $82 \%$ \\
\hline Female & $17 \%$ & $16 \%$ & $18 \%$ \\
\hline \multicolumn{4}{|l|}{ Learning Style } \\
\hline Experiential & $44 \%$ & $52 \%$ & $38 \%$ \\
\hline Other & $56 \%$ & $48 \%$ & $62 \%$ \\
\hline \multicolumn{4}{|l|}{ Class Standing } \\
\hline Sophomore & $29 \%$ & $44 \%$ & $15 \%$ \\
\hline Junior & $57 \%$ & $50 \%$ & $65 \%$ \\
\hline Senior & $14 \%$ & $6 \%$ & $20 \%$ \\
\hline \multicolumn{4}{|l|}{ Overall GPA } \\
\hline$>3.50$ & $32 \%$ & $34 \%$ & $29 \%$ \\
\hline $3.0-3.50$ & $38 \%$ & $47 \%$ & $30 \%$ \\
\hline$<3.0$ & $30 \%$ & $19 \%$ & $41 \%$ \\
\hline \multicolumn{4}{|l|}{ Prior Accounting GPA } \\
\hline$>3.50$ & $38 \%$ & $41 \%$ & $35 \%$ \\
\hline $3.0-3.50$ & $38 \%$ & $34 \%$ & $41 \%$ \\
\hline$<3.0$ & $24 \%$ & $25 \%$ & $24 \%$ \\
\hline \multicolumn{4}{|c|}{ Timing of Prior Accounting Course } \\
\hline Last semester & $21 \%$ & $28 \%$ & $15 \%$ \\
\hline Before last semester & $79 \%$ & $72 \%$ & $85 \%$ \\
\hline \multicolumn{4}{|c|}{ Prior Accounting Experience } \\
\hline One course & $7 \%$ & $10 \%$ & $3 \%$ \\
\hline Two courses & $87 \%$ & $80 \%$ & $94 \%$ \\
\hline Working experience & $6 \%$ & $10 \%$ & $3 \%$ \\
\hline
\end{tabular}

This table reports the participants' demographic information obtained before the start of the project. Learning Style is the student's description of his/her preferred learning style, including experiential learning and other (i.e., visual, auditory, reading/writing, and unknown). Prior Accounting GPA is the student's GPA in the introductory financial accounting course. Timing of Prior Accounting Course shows whether the student had the introductory financial accounting in the semester immediately before the project. Prior Accounting Experience includes one course - the introductory financial accounting, two courses - the introductory financial and managerial accounting, and related working experience in accounting. The subsample "Experiential Approach" reports student participants who completed the accounting cycle project in the simulation experiential learning approach. The subsample "Traditional Approach" reports student participants who completed the traditional accounting cycle project.

\section{Student Self-Assessment of the Project and of Learning Objectives}

We used student self-assessment questionnaires to validate the efficacy of the project based on student perceptions. Students responded to the questionnaires after completion of the project. Table 2 reports the mean and median values of their self-assessment. It shows that students in the simulation experiential learning approach rated the project highly. On a Likert scale of 1 (strongly disagree) to 5 (strongly agree), these students rated their overall assessment of the project at 4.21 . They felt that the project was effective 
for their learning of the accounting cycle (Question 1). They indicated that the project provided a business context (Question 2), was relevant (Question 3), and enabled them to see the big picture of financial reporting (Question 7). Most students believed that the project was at the right level of difficulty (Question 9 ) and would recommend it for future use in the course (Question 10).

\section{TABLE 2 STUDENT ASSESSMENT OF THE PROJECT}

\begin{tabular}{|c|c|c|c|}
\hline Survey Questions & Mean & Median & Difference \\
\hline $\begin{array}{l}\text { 1. The project was an effective assignment in learning } \\
\text { accounting cycle and financial reporting. }\end{array}$ & $\begin{array}{c}4.48 * * * \\
(35.10)\end{array}$ & $\begin{array}{l}5.00 * * * \\
(14.50)\end{array}$ & $\begin{array}{c}-0.92 \\
{[0.28]}\end{array}$ \\
\hline $\begin{array}{l}\text { 2. The project provided a real business context for learning } \\
\text { course topics. }\end{array}$ & $\begin{array}{c}4.34 * * * \\
(34.95)\end{array}$ & $\begin{array}{r}4.00^{* * * *} \\
(14.50)\end{array}$ & $\begin{array}{c}0.77 \\
{[0.16]}\end{array}$ \\
\hline 3. The project made course topics more relevant to me. & $\begin{array}{c}4.31 * * * \\
(38.45)\end{array}$ & $\begin{array}{r}4.00 * * * \\
(14.50)\end{array}$ & $\begin{array}{c}0.77 \\
{[0.26]}\end{array}$ \\
\hline $\begin{array}{l}\text { 4. The project was interesting. I was willing to put forth time } \\
\text { and effort. }\end{array}$ & $\begin{array}{r}4.24 * * * \\
(30.89)\end{array}$ & $\begin{array}{r}4.00^{* * * *} \\
(14.50)\end{array}$ & $\begin{array}{c}1.94^{*} \\
{[0.03]^{* *}}\end{array}$ \\
\hline $\begin{array}{l}\text { 5. The project required a broad range of skills (including basic } \\
\text { technical understanding of the topic and other more advanced } \\
\text { analytical skills). }\end{array}$ & $\begin{array}{l}4.24 * * * \\
(39.61)\end{array}$ & $\begin{array}{l}4.00 * * * \\
(14.50)\end{array}$ & $\begin{array}{c}2.20 * * \\
{[0.014]^{* *}}\end{array}$ \\
\hline $\begin{array}{l}\text { 6. The project helped me appreciate the role of the accounting } \\
\text { cycle in reporting and in deciding business activities. }\end{array}$ & $\begin{array}{c}4.14 * * * \\
(34.85)\end{array}$ & $\begin{array}{r}4.00 * * * \\
(14.50)\end{array}$ & $\begin{array}{c}-0.64 \\
{[0.19]}\end{array}$ \\
\hline $\begin{array}{l}\text { 7. The project enabled me to see the big picture of financial } \\
\text { reporting and business decisions. }\end{array}$ & $\begin{array}{r}4.38 * * * \\
(42.00)\end{array}$ & $\begin{array}{r}4.00 * * * \\
(14.50)\end{array}$ & $\begin{array}{c}0.98 \\
{[0.30]}\end{array}$ \\
\hline 8. The project helped me prepare for my planned future job. & $\begin{array}{c}3.55 * * * \\
(25.98) \\
\end{array}$ & $\begin{array}{c}4.00 * * * \\
(14.50)\end{array}$ & $\begin{array}{c}-0.53 \\
{[0.34]}\end{array}$ \\
\hline 9. The project was about the right level of difficulty. & $\begin{array}{c}4.07 * * * \\
(41.35) \\
\end{array}$ & $\begin{array}{c}4.00 * * * \\
(14.50)\end{array}$ & $\begin{array}{c}1.58 \\
{[0.11]}\end{array}$ \\
\hline 10. I would recommend this project for future use in the course. & $\begin{array}{c}4.38 * * * \\
(47.76)\end{array}$ & $\begin{array}{c}4.00 * * * \\
(14.50)\end{array}$ & $\begin{array}{c}1.31 \\
{[0.29]}\end{array}$ \\
\hline $\begin{array}{l}\text { Overall assessment: The students' average score of the above } \\
\text { ten survey questions. }\end{array}$ & $\begin{array}{c}4.21 * * * \\
(54.27) \\
\end{array}$ & $\begin{array}{c}4.20 * * * \\
(14.50) \\
\end{array}$ & $\begin{array}{c}0.57 \\
{[0.45]}\end{array}$ \\
\hline
\end{tabular}

This table reports the participants' assessment of the accounting cycle project after completing the project. A fivepoint Likert scale is used to measure their responses to each survey question: $1=$ strongly disagree, $2=$ disagree, $3=$ neutral, $4=$ agree, and $5=$ strongly agree. The mean and median values are student assessment in the simulation experiential learning approach. The numbers in parentheses are $t$-statistics for the mean values and sign-test scores for the medians. Difference reports the $t$-values of mean differences between the simulation experiential learning and traditional project approaches. The $p$-values of median score tests for the differences are presented in brackets. ***, $* *$, and $*$ denote $1 \%, 5 \%$, and $10 \%$ level of significance, respectively.

In addition, the "Difference" column in Table 2 reports the differences in student self-assessment between the simulation experiential learning approach and the traditional project approach. In their selfassessment, students in both approaches were positive about the project along the dimensions of project effectiveness, relevance, and difficulty appropriateness. Interestingly, students in the simulation experiential learning approach confirmed that the business simulation made the project more interesting and they were more willing to put forth time and effort into the project (Question 4). They also indicated that, with the business simulation, the project required a broad range of skills, including not only the basic procedural knowledge but also more advanced analytical skills (Question 5). These differences are statistically significant, suggesting that the simulation experiential learning approach enhanced student motivation. It also required and thus enabled students to use analytical skills to analyze and evaluate 
financial reports when they make and revise business decisions. This would support a high-level cognitive knowledge dimension of metacognition.

Table 3 summarizes student self-assessment of learning objectives. The first four survey questions relate to the factual, conceptual, and procedural knowledge dimensions. Specifically, students in the simulation experiential learning approach felt confident in preparation of journal entries, adjusting entries, and financial statements. They were also confident about procedures and technical skills needed to complete the accounting cycle. Student self-assessment of these learning objectives is statistically similar between the simulation experiential learning and traditional project approaches.

\section{TABLE 3 \\ STUDENT SELF-ASSESSMENT OF LEARNING}

\begin{tabular}{|c|c|c|c|}
\hline Survey Questions & Mean & Median & Difference \\
\hline \multicolumn{4}{|l|}{ Factual, conceptual, and procedural knowledge dimensions } \\
\hline 1. I know how to prepare journal entries and adjusting entries. & $\begin{array}{r}4.48 * * * \\
(42.02)\end{array}$ & $\begin{array}{l}5.00 * * * \\
(14.50)\end{array}$ & $\begin{array}{c}0.36 \\
{[0.35]}\end{array}$ \\
\hline 2. I know how to prepare financial statements. & $\begin{array}{r}4.31 * * * \\
(30.51)\end{array}$ & $\begin{array}{c}4.00 * * * \\
(14.50)\end{array}$ & $\begin{array}{c}0.14 \\
{[0.17]}\end{array}$ \\
\hline $\begin{array}{l}\text { 3. I know the steps required to complete an accounting cycle for } \\
\text { business activities. }\end{array}$ & $\begin{array}{r}4.14 * * * \\
(30.00)\end{array}$ & $\begin{array}{c}4.00 * * * \\
(14.50) \\
\end{array}$ & $\begin{array}{l}-1.02 \\
{[0.22]}\end{array}$ \\
\hline $\begin{array}{l}\text { 4. I feel confident about my overall technical skills in completing } \\
\text { an accounting cycle. }\end{array}$ & $\begin{array}{r}4.07 * * * \\
(31.14)\end{array}$ & $\begin{array}{l}4.00^{* * *} \\
(14.50)\end{array}$ & {$\left[\begin{array}{c}1.27 \\
{[0.097]^{*}}\end{array}\right.$} \\
\hline \multicolumn{4}{|l|}{ Metacognition knowledge dimension } \\
\hline $\begin{array}{l}\text { 5. I can use analytical skills to relate business activities to financial } \\
\text { reporting. }\end{array}$ & $\begin{array}{r}4.03 * * * \\
(31.93) \\
\end{array}$ & $\begin{array}{c}4.00 * * * \\
(14.50) \\
\end{array}$ & $\begin{array}{l}-0.87 \\
{[0.18]}\end{array}$ \\
\hline $\begin{array}{l}\text { 6. I can use analytical skills to analyze the impact of business } \\
\text { activities on financial reporting. }\end{array}$ & $\begin{array}{l}4.00 * * * \\
(26.87)\end{array}$ & $\begin{array}{l}4.00 * * * \\
(14.50) \\
\end{array}$ & $\begin{array}{c}0.00 \\
{[0.41]}\end{array}$ \\
\hline $\begin{array}{l}\text { 7. I can use analytical skills to analyze financial reports and relate } \\
\text { business performance to business activities. }\end{array}$ & $\begin{array}{r}4.03 * * * \\
(31.93)\end{array}$ & $\begin{array}{l}4.00^{* * *} \\
(14.50)\end{array}$ & $\begin{array}{l}-0.42 \\
{[0.36]}\end{array}$ \\
\hline $\begin{array}{l}\text { 8. I can use critical-thinking skills to suggest/decide future business } \\
\text { activities based on my analysis of current business activities and } \\
\text { financial reports. }\end{array}$ & $\begin{array}{r}4.14 * * * \\
(32.15)\end{array}$ & $\begin{array}{c}4.00 * * * \\
(14.50)\end{array}$ & $\begin{array}{l}1.21 \\
{[0.17]}\end{array}$ \\
\hline \multicolumn{4}{|l|}{ Overall self-assessment } \\
\hline $\begin{array}{l}\text { 9. I feel better prepared to work for a real business in its accounting } \\
\text { cycle and financial reporting. }\end{array}$ & $\begin{array}{r}4.10 * * * \\
(39.67)\end{array}$ & $\begin{array}{c}4.00 * * * \\
(14.50)\end{array}$ & $\begin{array}{l}-0.46 \\
{[0.26]}\end{array}$ \\
\hline $\begin{array}{l}\text { Overall assessment: The students' average score of the above nine } \\
\text { survey questions. }\end{array}$ & $\begin{array}{r}4.15^{* * * *} \\
(48.02)\end{array}$ & $\begin{array}{c}4.11 * * * \\
(14.50)\end{array}$ & $\begin{array}{c}0.12 \\
{[0.25]}\end{array}$ \\
\hline
\end{tabular}

This table reports the participants' assessment of learning objectives after completing the accounting cycle project. A five-point Likert scale is used to measure their responses to each survey question: $1=$ strongly disagree, $2=$ disagree, $3=$ neutral, $4=$ agree, and $5=$ strongly agree. The mean and median values are student assessment in the simulation experiential learning approach. The numbers in parentheses are $t$-statistics for the mean values and sign-test scores for the medians. Difference reports the $t$-values of mean differences between the simulation experiential learning and traditional project approaches. The $p$-values of median score tests for the differences are presented in brackets. ***, $* *$, and $*$ denote $1 \%, 5 \%$, and $10 \%$ level of significance, respectively.

Survey questions 5 through 8 relate to the metacognition knowledge dimension. These questions ask students to self-assess their analytical skills to relate business activities to financial reports, to analyze the impact of business activities, and to evaluate financial reports for subsequent business decisions. Students in the simulation experiential learning approach, on average, were positive about their analytical skills and metacognition knowledge. Although these students felt that more advanced analytical skills were required in the simulation experiential learning approach (Table 2, Question 5), their self-assessment of analytical 
skills after completing the project was statistically indifferent from that of students in the traditional project approach. Upon completion of the accounting cycle project, all students felt better prepared for working in a real business's accounting cycle and financial reporting (Question 9).

\section{Student Pre- vs. Post-Project Knowledge Tests}

To further assess student learning in the simulation experiential learning approach, we implemented pre- and post-project knowledge tests (in a multiple-choice question format) to examine student performance in the factual, conceptual, procedural, and metacognition knowledge dimensions of the accounting cycle. As Table 4 shows, we designed the first six questions along the factual, conceptual and procedural knowledge dimensions. These questions, for instance, ask about examples of assets, debits and credits, T-accounts, and closing procedures. The remaining four multiple-choice questions emphasize the metacognition dimension. These questions require students to relate busines transactions to financial statements and to analyze these relationships and the impacts of business decisions. Students answered the same ten multiple-choice questions before and after completing the project. Note that student pre-project performance was primarily based on their knowledge from the prior introductory financial accounting course.

TABLE 4

PRE- VS. POST-PROJECT STUDENT PERFORMANCE

\begin{tabular}{|c|c|c|c|c|}
\hline Multiple-Choice Questions & $\begin{array}{c}\text { Pre- } \\
\text { Project }\end{array}$ & $\begin{array}{l}\text { Post- } \\
\text { Project }\end{array}$ & Diff. 1 & Diff. 2 \\
\hline \multicolumn{5}{|c|}{ Factual, conceptual, and procedural knowledge dimensions } \\
\hline $\begin{array}{l}\text { 1. The assets of a company include: (B) for } \\
\text { example, cash, accounts receivable and } \\
\text { merchandise inventory. }\end{array}$ & $\begin{array}{c}84 \% * * * \\
(12.49)\end{array}$ & $\begin{array}{l}100 \% * * * \\
(\mathrm{n} / \mathrm{a})\end{array}$ & $\begin{array}{l}2.40^{* *} \\
{[0.011]^{* *}}\end{array}$ & $\begin{array}{c}1.00 \\
{[0.16]}\end{array}$ \\
\hline $\begin{array}{l}\text { 2. A credit entry to an account would: }(\mathrm{C}) \text { increase } \\
\text { common stock. }\end{array}$ & $\begin{array}{c}35 \% * * * \\
(4.06)\end{array}$ & $\begin{array}{c}97 \% * * * \\
(30.00)\end{array}$ & $\begin{array}{c}6.58 * * * \\
{[<.0001]^{* * *}}\end{array}$ & $\begin{array}{c}1.70^{*} \\
{[0.048]^{* *}}\end{array}$ \\
\hline $\begin{array}{l}\text { 3. A company's unearned revenue }(\mathrm{U} / \mathrm{R}) \text { had a } \\
\text { beginning balance of } \$ 6,000 \text {. During the period, } \\
\text { there were debit postings of } \$ 1,000 \text { and credit } \\
\text { postings of } \$ 500 \text { to this account. Which of the } \\
\text { following T-accounts is correct for its } U / \mathrm{R} \text { for } \\
\text { this period? }\end{array}$ & $\begin{array}{c}35 \% * * * \\
(4.06)\end{array}$ & $\begin{array}{l}100 \% * * * \\
(\mathrm{n} / \mathrm{a})\end{array}$ & $\begin{array}{c}7.39 * * * \\
{[<.0001]^{* * *}}\end{array}$ & $\begin{array}{c}2.10 * * \\
{[0.02]^{* *}}\end{array}$ \\
\hline $\begin{array}{l}\text { 4. A company's beginning balance of Prepaid } \\
\text { Rent was } \$ 3,000 \text {. At the end of the period, the } \\
\text { balance was } \$ 1,000 \text {. If the company paid } \\
\text { additional } \$ 7,000 \text { in the period for its Prepaid } \\
\text { Rent, which of the following T-accounts is the } \\
\text { correct to reflect the status of the company's } \\
\text { Prepaid Rent in this period? }\end{array}$ & $\begin{array}{c}71 \% * * * \\
(8.56)\end{array}$ & $\begin{array}{c}84 \% * * * \\
(12.49)\end{array}$ & $\begin{array}{c}1.21 \\
{[0.11]}\end{array}$ & $\begin{array}{c}-0.05 \\
{[0.48]}\end{array}$ \\
\hline $\begin{array}{l}\text { 5. Which of the following accounts is not closed } \\
\text { at the end of an accounting cycle? (B) Interest } \\
\text { payable. }\end{array}$ & $\begin{array}{c}61 \% * * * \\
(6.89)\end{array}$ & $\begin{array}{c}100 \% * * * \\
(\mathrm{n} / \mathrm{a})\end{array}$ & $\begin{array}{c}4.35 * * * \\
{[<.0001]^{* * *}}\end{array}$ & {$[0.50]$} \\
\hline $\begin{array}{l}\text { 6. When a corporation purchases a computer for } \\
\text { cash, its (D) cash account will be credited. }\end{array}$ & $\begin{array}{c}81 \% * * * \\
(11.18)\end{array}$ & $\begin{array}{c}100 \% * * * \\
(\mathrm{n} / \mathrm{a})\end{array}$ & $\begin{array}{c}2.68 * * \\
{[0.005]^{* * *}}\end{array}$ & $\begin{array}{c}1.44 \\
{[0.08]^{*}}\end{array}$ \\
\hline
\end{tabular}




\begin{tabular}{|c|c|c|c|c|}
\hline \multicolumn{5}{|l|}{ Metacognition knowledge dimension } \\
\hline $\begin{array}{l}\text { 7. A company performed and provided services } \\
\text { and its customer promised to pay in the future. } \\
\text { For this company, this transaction would: } \\
\text { (C) increase its owners' equity. }\end{array}$ & $\begin{array}{c}29 \% * * * \\
(3.50)\end{array}$ & $\begin{array}{c}58 \% * * * \\
(6.45)\end{array}$ & $\begin{array}{c}2.37 * * \\
{[0.011]^{* *}}\end{array}$ & $\begin{array}{c}1.64 \\
{[0.053]^{*}}\end{array}$ \\
\hline $\begin{array}{l}\text { 8. Which of the following transactions will } \\
\text { increase a company's net income? }(\mathrm{C}) \\
\text { Decreasing its advertisement spending for the } \\
\text { period. }\end{array}$ & $\begin{array}{c}71 \% * * * \\
(8.56)\end{array}$ & $\begin{array}{c}94 \% * * * \\
(20.86)\end{array}$ & $\begin{array}{c}2.40^{* *} \\
{[0.011]^{* *}}\end{array}$ & $\begin{array}{c}1.48 \\
{[0.07]^{*}}\end{array}$ \\
\hline $\begin{array}{l}\text { 9. Which of the following transactions will } \\
\text { increase a company's total assets without } \\
\text { increasing its liabilities? (B) Issuing common } \\
\text { stock for cash. }\end{array}$ & $\begin{array}{c}68 \% * * * \\
(7.94)\end{array}$ & $\begin{array}{c}100 \% * * * \\
(\mathrm{n} / \mathrm{a})\end{array}$ & $\begin{array}{c}3.78 * * * \\
{[0.0003]^{* * *}}\end{array}$ & $\begin{array}{c}1.44 \\
{[0.08]^{*}}\end{array}$ \\
\hline $\begin{array}{l}\text { 10. A local business began the year with total } \\
\text { assets of } \$ 100,000 \text { and total liabilities of } \\
\$ 30,000 \text {. During the year, the business issued } \\
\text { additional stock } \$ 20,000 \text {. It also had net income } \\
\text { of } \$ 10,000 \text {, declared dividends of } \$ 1,000 \text {. How } \\
\text { much was its owners' equity on December } 31 \text { ? } \\
\text { (C) } \$ 99,000 \text {. }\end{array}$ & $\begin{array}{c}48 \% * * * \\
(5.30)\end{array}$ & $\begin{array}{l}71 \% * * * \\
(8.56)\end{array}$ & $\begin{array}{c}1.83^{*} \\
{[0.04]^{* *}}\end{array}$ & $\begin{array}{c}2.93 * * * \\
{[0.003]^{* * *}}\end{array}$ \\
\hline $\begin{array}{l}\text { Overall performance: The average of student scores } \\
\text { of the above ten multiple-choice questions. }\end{array}$ & $\begin{array}{c}58 \% * * * \\
(12.78)\end{array}$ & $\begin{array}{c}90 \% * * * \\
(47.97)\end{array}$ & $\begin{array}{c}6.46^{* * *} \\
{[<.0001]^{* * *}}\end{array}$ & $\begin{array}{c}1.69^{*} \\
{[0.03]^{* *}}\end{array}$ \\
\hline
\end{tabular}

This table reports the participants' performance both before and after completing the accounting cycle project. The Pre-Project and Post-Project values are student performance in the simulation experiential learning approach. The values for each multiple-choice question are the percentages of students who answered the question correctly. The numbers in parentheses are $t$-statistics. Diff. 1 reports the $t$-values of differences between pre- and post-project in the simulation experiential learning approach. Diff. 2 reports the differences of student post-project performance between the simulation experiential learning and traditional project approaches. The $p$-values of median score tests for the differences are presented in brackets. $* * * * *$, and $*$ denote $1 \%, 5 \%$, and $10 \%$ level of significance, respectively.

Results in Table 4 support the efficacy of the simulation experiential learning approach. The table shows that students, on average, performed well upon completion of the project. The overall performance was $90 \%$ correct, significantly higher than the overall score of $58 \%$ before the project. The improvement in student performance is substantial and statistically significant in the dimensions of both factual, conceptual, and procedural (Questions 1-6), and metacognition (Questions 7-10). In addition, we compare student performance between the simulation experiential learning and traditional project approaches after completing the project. Table 4 suggests that students in the simulation experiential learning approach performed marginally better in answering Questions 7-9 while significantly better in Question 10 in the metacognition knowledge dimension.

Table 5 reports the regression results of student performance. We control for student characteristics, including major, gender, learning style, class standing, overall GPA, timing of prior introductory financial accounting course, and prior experience in the accounting field. Alternatively, the GPA in prior introductory financial accounting course was used in the regression models. The results are statistically similar. Models (1a) and (1b) examine students who participated in the simulation experiential learning approach. It compares their post-project performance to pre-project performance. The "Pre- vs. Post-Project Dummy" variable is statistically positive and significant, suggesting that students made substantial improvement and performed significantly better upon completion of the simulation project. ${ }^{6}$

Models (2a) and (2b) analyze and compare post-project performance of the students in the simulation experiential learning approach to that of the students in the traditional project approach. Consistent with the results in Table 4, the variable, "Project Approach Dummy" suggests that students in the simulation 
experiential learning approach performed marginally better after controlling for student characteristics. Interestingly, the variable "Learning Style" is statistically insignificant in these models. This suggests that our simulation experiential learning approach may improve student performance regardless of their preferred learning style.

TABLE 5

REGRESSIONS OF STUDENT PERFORMANCE

\begin{tabular}{|c|c|c|c|c|}
\hline Dependent variable & \multicolumn{2}{|c|}{ Student Performance } & \multicolumn{2}{|c|}{ Post-Project Performance } \\
\hline Model & (1a) & (1b) & $(2 a)$ & (2b) \\
\hline Intercept & $\begin{array}{c}0.49 * * \\
(2.12)\end{array}$ & $\begin{array}{c}0.04 \\
(0.25)\end{array}$ & $\begin{array}{c}0.71 * * * \\
(6.11)\end{array}$ & $\begin{array}{c}0.63 * * * \\
(7.55)\end{array}$ \\
\hline Pre- vs. Post-Project Dummy & $\begin{array}{c}0.32 * * * \\
(7.39)\end{array}$ & $\begin{array}{c}0.32 * * * \\
(7.09)\end{array}$ & & \\
\hline Project Approach Dummy & & & $\begin{array}{l}0.05^{*} \\
(1.82)\end{array}$ & $\begin{array}{l}0.03 * \\
(1.70)\end{array}$ \\
\hline Major & $\begin{array}{l}0.13 * * \\
(2.12)\end{array}$ & $\begin{array}{l}0.12 * * \\
(2.27)\end{array}$ & $\begin{array}{c}0.01 \\
(0.16)\end{array}$ & \\
\hline Gender & $\begin{array}{c}-0.27 * * * \\
(-3.64)\end{array}$ & $\begin{array}{c}-0.23 * * * \\
(-3.04)\end{array}$ & $\begin{array}{c}-0.09 * * \\
(-2.31)\end{array}$ & $\begin{array}{c}-0.08 * * * \\
(-2.35)\end{array}$ \\
\hline Learning Style & $\begin{array}{c}-0.09 \\
(-1.63) \\
\end{array}$ & & $\begin{array}{c}-0.03 \\
(-0.93) \\
\end{array}$ & \\
\hline Class Standing & $\begin{array}{l}-0.12^{*} \\
(-1.81)\end{array}$ & & $\begin{array}{c}0.02 \\
(0.59)\end{array}$ & \\
\hline Overall GPA & $\begin{array}{l}0.11 * * \\
(2.07)\end{array}$ & $\begin{array}{c}0.16^{* * *} \\
(3.09)\end{array}$ & $\begin{array}{c}0.07 * * * \\
(2.70)\end{array}$ & $\begin{array}{c}0.07 * * * \\
(2.73)\end{array}$ \\
\hline Timing of Prior Accounting Course & $\begin{array}{l}-0.13^{*} \\
(-1.68)\end{array}$ & & $\begin{array}{c}-0.05 \\
(-0.90)\end{array}$ & \\
\hline Prior Accounting Experience & $\begin{array}{c}-0.15 \\
(-1.64)\end{array}$ & & $\begin{array}{c}-0.09 \\
(-1.44)\end{array}$ & \\
\hline Adjusted $\mathrm{R}^{2}$ & 0.56 & 0.51 & 0.14 & 0.16 \\
\hline F-value & 10.39 & 16.49 & 2.28 & 5.06 \\
\hline
\end{tabular}

This table reports regression results of student performance in the project. Student Performance is the student's score in the assigned ten multiple-choice questions. Post-Project Performance is the student's score in the assigned ten multiple-choice questions taken after completing the project. Models (1a) and (1b) examine Student Performance in the simulation experiential learning approach. Models (2a) and (2b) compare student Post-Project Performance between the simulation experiential learning and traditional project approaches. The variable, "Pre- vs. Post-Project Dummy" equals 1 if post-project performance, and zero if pre-project. The variable, "Project Approach Dummy" equals 1 if the simulation experiential learning approach was used, and zero if the traditional approach was used for the project. The numbers in parentheses are $t$-statistics. ${ }^{* *},{ }^{* *}$, and $*$ denote $1 \%, 5 \%$, and $10 \%$ level of significance, respectively.

\section{CONCLUDING REMARKS}

Prior literature has discussed the importance of experiential learning to engage learners in the fourstage cycle: to create and experience, observe and reflect, analyze and theorize, and modify and test in learning subject matter. Our simulation experiential learning approach integrated a business simulation into an accounting cycle project. It enabled students to (1) create business transactions, (2) complete accounting cycle procedures, (3) analyze and compare their business performance, and (4) make and modify future business decisions in a quasi-"real world" context for a classroom activity. 
Most students rated the project effective and relevant. Students in the simulation experiential learning approach, as compared to those in the traditional project approach, felt that the project was more interesting, and they seemed more motivated to put forth time and effort on the project. These students also felt that the simulation experiential learning approach required a broad range of skills (i.e., both basic technical understanding of the topic and other more advanced analytical skills). Upon completion of the project, these students made significant improvement along all four knowledge dimensions (i.e., factual, conceptual, procedural, and metacognition) of the accounting cycle. Although they did not report greater confidence in their self-assessment of analytical skills, they performed better, as compared to those who participated in the traditional project approach, in the post-project knowledge tests in answering multiple-choice questions in the metacognition dimension. These results are consistent with Everaert et al. (2017) which suggested that both high intrinsic and extrinsic motivations of the learner could positively impact deep learning and deep learning would lead to higher academic performance.

We acknowledge a few limitations in our project. First, our institution is a private university. The average class size is about 25-35 students in an intermediate accounting class, which may differ from other institutions. Second, we used the project in a traditional in-person class setting. It can be modified for blended, online, or flipped classes. Last, additional analytical components may also be integrated into the project, for example, financial statement analysis and income tax consequences. However, considering the length of the project and time constraints in a given course, although our project does not cover all aspects of the accounting cycle for business decision making, its simulation experiential learning approach can be adopted and may improve student learning of the subject matter.

\section{ACKNOWLEDGEMENTS}

We thank Timothy Fogarty, Diane Matson, Gary Previts, and seminar participants at the 2021 North American Accounting Society Annual Conference for comments and suggestions. For business simulation used in this study, we acquired an institutional license for GoVenture Accounting Game from MediaSpark, Inc. We conducted our study independently from MediaSpark, Inc. We obtained the permission from MediaSpark, Inc. for use of screenshots from its GoVenture Accounting Game in our manuscript. Any errors or omissions in the study are solely the responsibility of the authors.

\section{ENDNOTES}

1. Experiential learning has also been used to describe internship experience, job simulation and work experience.

2. We acquired an institutional license for GoVenture Accounting Game. We conducted our study independently from GoVenture Accounting Game and MediaSpark, Inc. We are responsible for any errors or omissions.

3. GoVenture Accounting Game offers a series of business activities, in a virtual environment, in which students make decisions daily. The interface of GoVenture Accounting Game is intuitive and user-friendly. However, its business activities are primarily cash-based. We modify these activities and include additional information to incorporate accrual-based transactions (see Appendix 2). The instructor can also modify these activities to emphasize other business transactions and the related journal entries and adjustments.

4. GoVenture Accounting Game offers both automated and manual accounting systems. In the former, the game produces the reports. In the latter, the players prepare the reports. In Phase 1, we use the automated version to ensure that students focus on making and revising their daily business decisions, based on their use and analysis of the business and financial reports automatically generated. In Phase 2, we provide students with additional information and they prepare their own accrual-based accounting records and financial reports in an Excel document.

5. We obtained approval from our university's Institutional Review Board (IRB) for the use of human subjects to collect student data.

6. The variable "Major" is highly correlated with variables "Class Standing" and "Timing of Prior Accounting Course." Accounting students tend to take the intermediate accounting course earlier and immediately after their introductory financial accounting course. It is a prerequisite to further accounting courses. Finance 
majors may delay it because it is not a prerequisite to any further finance courses. To mitigate possible high collinearity issues in our regression models, we also ran the regression models (1b) and (2b). The "Pre- vs. Post-Project Dummy" variable in model (1b) and the "Project Approach Dummy" variable in model (2b), respectively, remain statistically significant.

\section{REFERENCES}

Anderson, L.W., \& Krathwohl, D.R. (2001). A Taxonomy for Learning, Teaching, and Assessing: A Revision of Bloom's Taxonomy of Educational Objectives. New York, NY: Addison Wesley Longman.

Bergner, J., \& Brooks, M. (2017). The efficacy of using Monopoly to improve undergraduate students' understanding of the accounting cycle. Advances in Accounting Education: Teaching and Curriculum Innovations, 20, 33-50.

Blankley, A.I., Kerr, D., \& Wiggins, C.E. (2017). The state of accounting education in business schools: An examination and analysis of active learning techniques. Advances in Accounting Education: Teaching and Curriculum Innovations, 21, 101-124.

Bloom, B.S. (Ed.), Engelhart, M.D., Furst, E.J., Hill, W.H., \& Krathwohl, D.R. (1956). Taxonomy of Educational Objectives: Handbook I: Cognitive Domain. New York: David McKay.

Brink, A.G. (2013). The impact of pre- and post-lecture quizzes on performance in Intermediate Accounting II. Issues in Accounting Education, 28(3), 461-285.

Butler, M.G., Church, K.S., \& Spencer, A.W. (2019). Do, reflect, think, apply: Experiential education in accounting. Journal of Accounting Education, 48, 12-21.

Chmielewski-Raimondo, D.A., McKeown, W., \& Brooks, A. (2016). The field as our classroom: Applications in a business-related setting. Journal of Accounting Education, 34, 41-58.

Dewey, J. (1897). My pedagogic creed. School Journal, 54(3), 77-80.

Dewey, J. (1938). Experience and Education. New York: Simon \&Schuster.

Everaert, P., Opdecam, E., \& Maussen, S. (2017). The relationship between motivation, learning approaches, academic performance and time spent. Accounting Education, 26(1), 78-107.

Fanning, K., \& Grant, R. (2017). Manual vs. computerized practice set: Which achieves learning objectives the best? AIS Educator Journal, 12(1), 25-33.

Green, B.P., \& Calderon, T.G. (2005). Assessing student learning and growth through audit risk simulations. Advances in Accounting Education: Teaching and Curriculum Innovations, 7, 1-25.

Gittings, L., Taplin, R., \& Kerr, R. (2020). Experiential learning activities in university accounting education: A systematic literature review. Journal of Accounting Education, 52(3), 1-13.

Huber, M., Law, D., \& Khallaf, A. (2017). Active learning innovations in introductory financial accounting. Advances in Accounting Education: Teaching and Curriculum Innovations, 21, 125167.

Jones, J.P., Long, J.H., \& Stanley, J.D. (2019). Pane in the glass: A review of the accounting cycle. Issues in Accounting Education, 34(1), 35-50.

Jones, K., \& Roberts, B. (2005). Revisiting the use of a fundamental (accounting cycle) practice set in intermediate accounting 1. Journal of Accounting Finance Research, 13(5), 35-44.

Kolb, D.A., \& Fry, R. (1975). Towards an applied theory of experiential learning. In C. Cooper (Ed.), Theories of Group Processes (pp. 33-57). New York, NY: John Wiley \& Sons.

Kolb, D.A. (1984). Experiential Learning: Experience as the Source of Learning and Development. Englewood Cliffs, NJ: Prentice-Hall.

Kolb, A., \& Kolb, D.A. (2005). Learning styles and learning spaces: Enhancing experiential learning in higher education. Academy of Management Learning and Education, 4(2), 193-212.

Lafond, C.A., \& Wentzel, K. (2015). Cost accumulation in small businesses: Experiential learning project. Advances in Accounting Education: Teaching and Curriculum Innovations, 16, 45-63.

Lewin, K., Lippitt, R., \& White, R.K. (1939). Patterns of aggressive behavior in experimentally treated "social climates." Journal of Social Psychology, 10, 271-299. 
McCarthy, M. (2010). Experiential learning theory: From theory to practice. Journal of Business and Economics Research, 8(5), 131-139.

Phillips, M.E., \& Graeff, T.R. (2014). Using an in-class simulation in the first accounting class: Moving from surface to deep learning. Journal of Education for Business, 89(5), 241-247.

Porter, J.C. (2019). Beyond debits and credits: Using integrated projects to improve students' understanding of financial accounting. Journal of Accounting Education, 46, 53-71.

Sargent, C.S. (2013). Find it, fix it, and thrive: The impact of insisting on proficiency in prerequisite knowledge in intermediate accounting. Issues in Accounting Education, 28(3), 581-597.

Zeigler, J.F. (2015). Pedagogy change in undergraduate managerial accounting principles courses: A detailed review of simulation use to support business integration learning, teamwork, and assessment. Advances in Accounting Education: Teaching and Curriculum Innovations, 17, 4570.

APPENDIX 1: A SERIES OF SCREENSHOTS FROM GOVENTURE ACCOUNTING GAME

\section{APPENDIX 1.1 \\ GOVENTURE ACCOUNTING GAME INTERFACE}

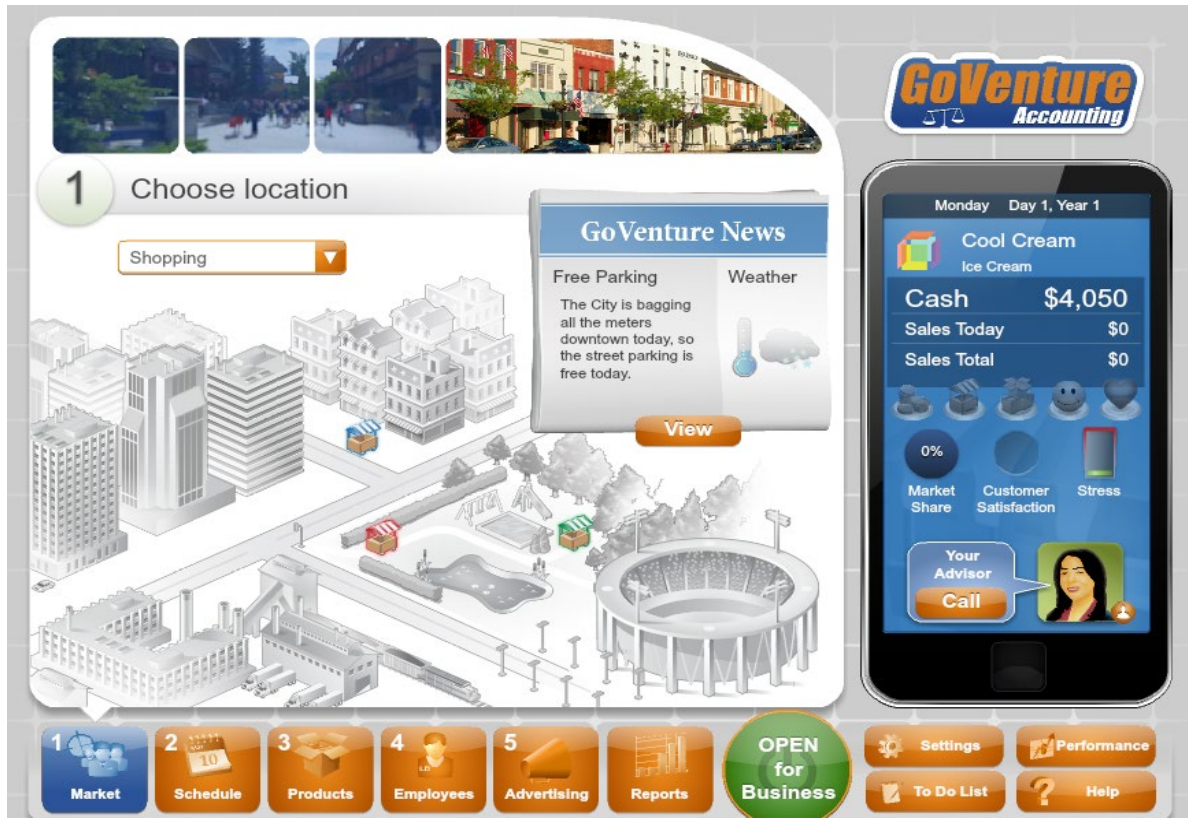


APPENDIX 1.2

A DAILY REPORT ON SALES AND COST OF GOODS SOLD

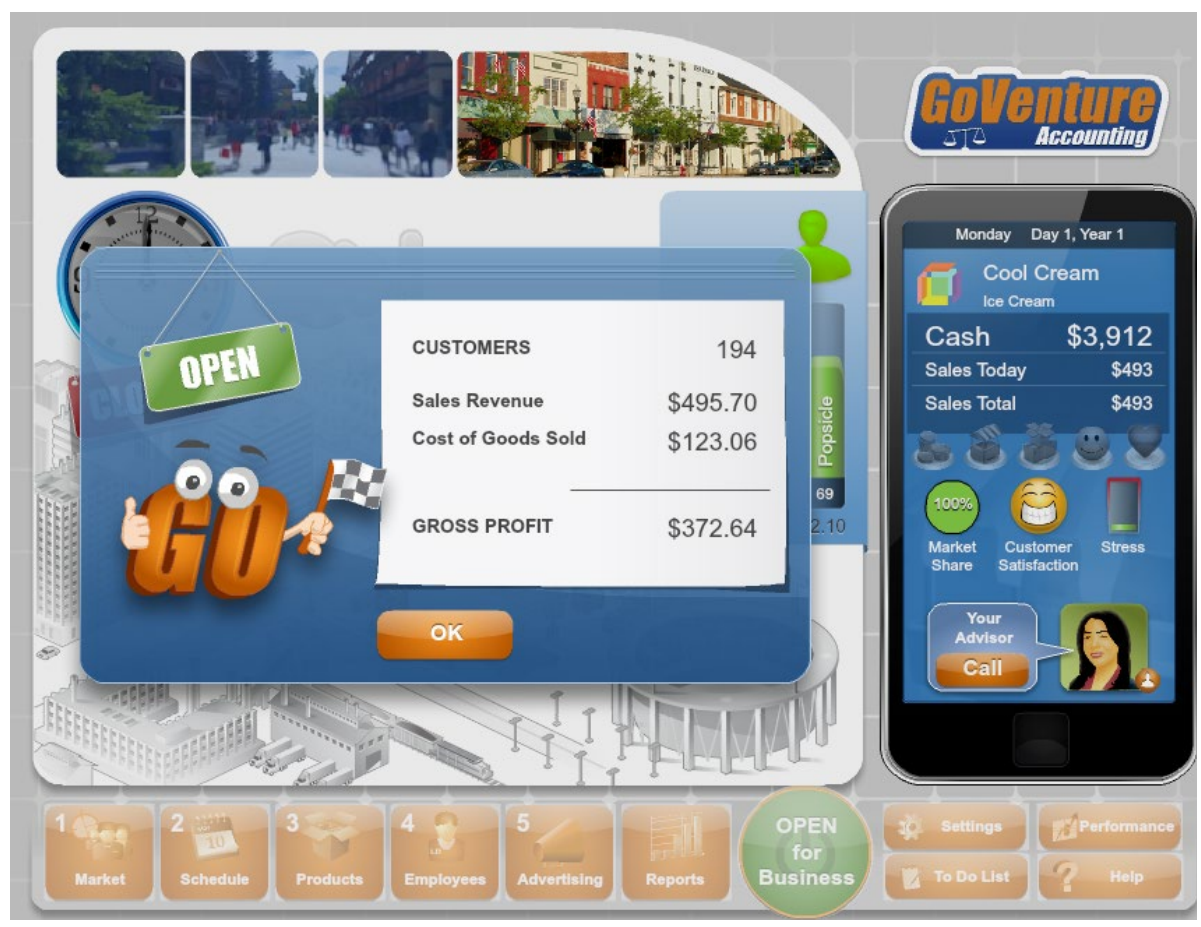

APPENDIX 1.3

AUTOMATED BUSINESS AND FINANCIAL REPORTS

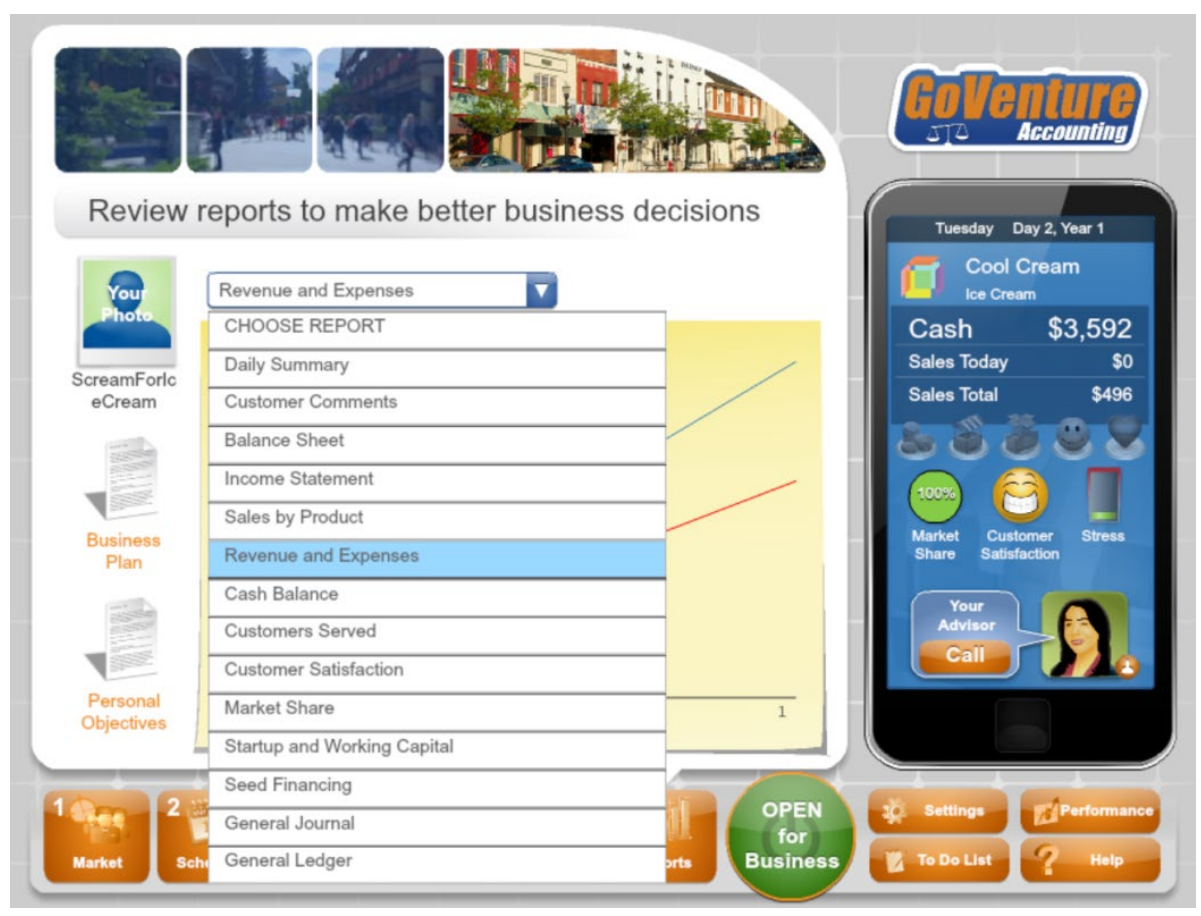




\section{APPENDIX 1.4 \\ AN AUTOMATED INCOME STATEMENT}

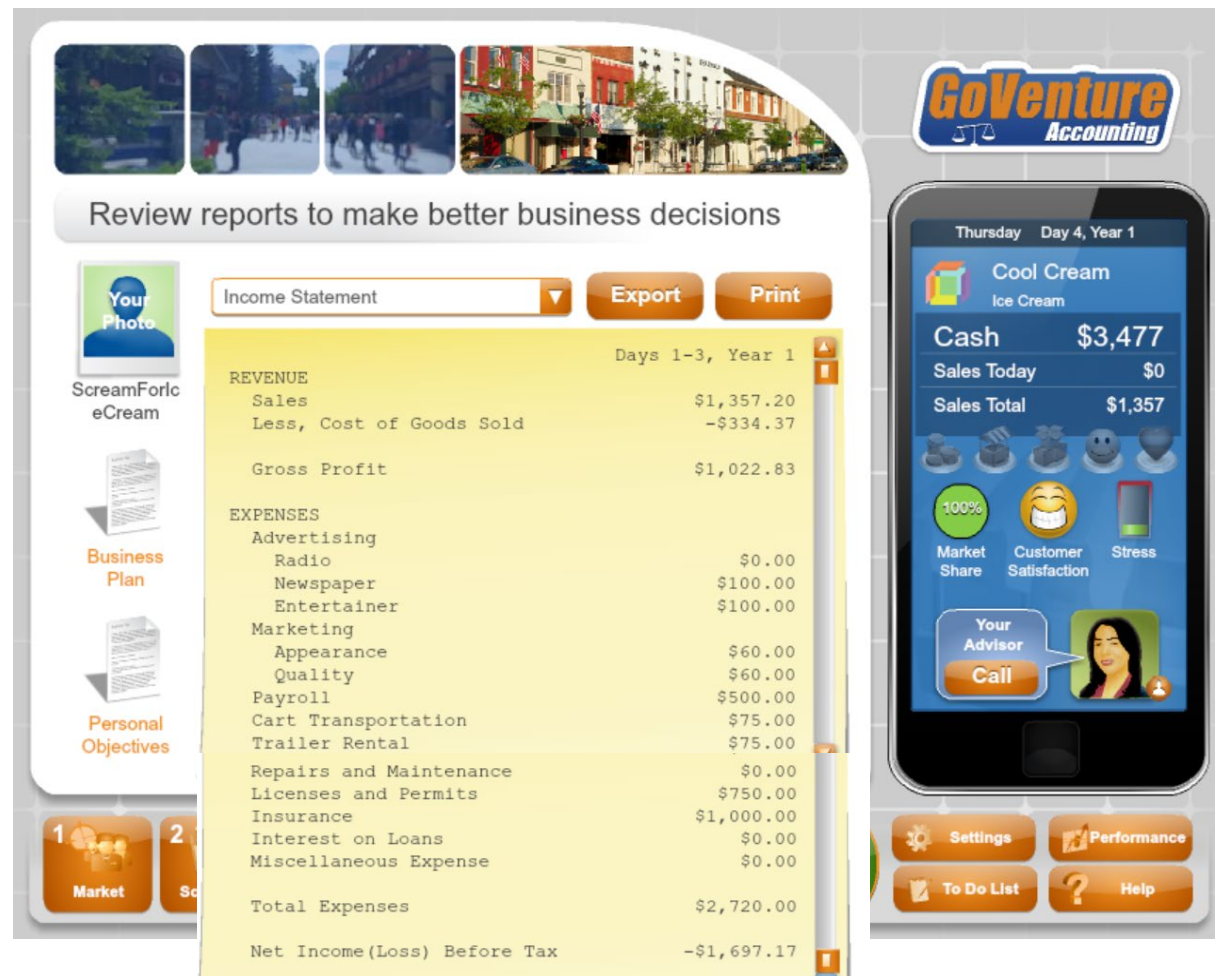

\section{APPENDIX 2: A LIST OF BUSINESS TRANSACTIONS ADAPTED TO GOVENTURE ACCOUNTING GAME}

You started a mobile street cart business at the beginning of February. During February, the following business activities occurred.

1. You, the owner(s), contributed $\$ 1,000$ cash to the business on February 1 .

2. On February 1, your company borrowed $\$ 9,000$ from a local bank, on a $10 \%$ note for 5 years. The interest would be paid semi-annually on each August 1 and February 1.

3. On February 1, your company paid $\$ 750$ fees to local government agencies for business licenses and permits, for a period of one year.

4. On February 1, your company acquired a mobile cart, a business sign, and other equipment for a total of $\$ 4,200$ (all paid in cash). You estimated that the life of these PP\&E items was 2 years with a residual value of $\$ 300$.

5. On February 1, your company paid $\$ 1,000$ for its annual insurance; the policy started on February 1.

6. During February, your company acquired merchandise, totaling $\$$ (provided by your simulation). At the time of purchase, $70 \%$ of the merchandise was acquired on account. Your company promised to pay the remaining balances in 20 days.

7. For the merchandise purchases in Transaction 6, toward the end of February your company paid an additional $20 \%$ of the total merchandise price in cash to its suppliers.

8. During February, your company delivered merchandise and earned $\$$ sales revenue (provided by your simulation), of which $30 \%$ was on credit. The cost, to your company, of the merchandise sold, was $\$$ (provided by your simulation). 
9. On February 28, your company signed a sales contract with a customer, Mini-Soda Company, to deliver a total of $\$ 5,000$ in merchandise on March 7. Your company collected $\$ 2,000$ cash in advance from this customer on February 28.

10. By the end of February, your company collected $50 \%$ of its accounts receivable from various customers from Transaction 8.

11. By the end of February, your company incurred and paid a total of $\$$ (provided by your simulation) in cash for its other selling expenses (including advertising, marketing, payroll, cart transportation, trailer rental, etc.)

The following information was also available during February for your company.

12. Your company incurred monthly interest expense on its debt borrowing as described in Transaction 2.

13. At the end of February, your prepayment, from Transaction 3, on business licenses and permits expired for the month.

14. As described in Transaction 4, your company's PP\&E had an estimated life of two years with a $\$ 300$ residual value. Your company used the straight-line depreciation method.

15. At the end of February, your prepayment, from Transaction 5, on insurance expired for the month.

16. At the end of February, your company estimated $10 \%$ of its outstanding accounts receivable as possibly uncollectible.

17. The income tax rate was $20 \%$ for your company. Taxes would be paid in March. 